\title{
Implementation of Industrial Work Practice Management
}

\author{
Uli Anto Hutagalung ${ }^{1, *}$ Zainuddin $^{2}$ Edidon Hutasuhut ${ }^{3}$
}

\author{
${ }^{1}$ Universitas Muhammadiyah Tapanuli Selatan North Sumatra Indonesia \\ ${ }^{2,3}$ Postgraduate School Universitas Negeri Medan North Sumatra, Indonesia \\ *Corresponding author. Email: uliantohutagalung@gmail.com
}

\begin{abstract}
Vocational High Schools aims to improve the ability of students to be able to develop themselves in line with the development of science, technology, and prepare students to enter the world of work; one way is through the implementation of industrial work practices. This study aims to describe the management of industrial work practices at SMK Negeri 1 Manduamas, which focuses on aspects of planning, implementing and evaluating. Data collection technique are interviews and documentation. Data analysis procedures are data reduction, data exposure and data analysis. The results showed that the Industrial Work Practice management at SMK Negeri 1 Manduamas consisted of planning carried out in the new academic year. The implementation carried out into 2 periods for a year, and evaluation carried out after industrial work practices ended to find out the shortcomings and achievements of the industrial work practices implementation.
\end{abstract}

Keywords: strategy, leadership, technology, communication.

\section{INTRODUCTION}

Education based on the Law of the Republic of Indonesia Number 20 of 2003 concerning the National Education System Chapter 1 Article 1: Education is a conscious and planned effort to create a learning atmosphere and learning process so that students actively develop their potential to have religious spiritual strength, self-control, personality, intelligence, noble character, and skills needed by himself, society, nation and state. An important element that plays a role in determining the success of education is the school, including the Vocational High School [1].

SMK according to the National Education System listed in the curriculum document of SMK Negeri 1 Manduamas is vocational secondary education is education at the secondary education level that prioritizes developing the ability of students to be able to work in certain fields, the ability to adapt in the work environment, see job opportunities, and develop themselves in the future [2]. Vocational Schools are responsible for preparing students to be able to work according to their fields of expertise, so that students have skills in their fields of expertise well. Vocational High Schools must provide programs that can improve the competency skills possessed by students before entering the world of work/industry. These programs include implementing industrial work practices [3].

According to the Directorate of Vocational High School Development states that: industrial work practices which are abbreviated as practical are part of a learning program that must be carried out by every student in the world of work, as a tangible manifestation of the implementation of the education system in vocational schools, namely Dual System Education (PSG). Further [4] explained that Vocational Schools practical aims to: 1) fulfil competencies according to the demands of the mastery curriculum, 2) implement competencies into the world of work, and 3) grow work ethic/work experience.

The results of a preliminary study that has been carried out by the author at SMK Negeri 1 Manduamas, through interviews with school teachers, show that in reality there are still problems that occur in the implementation of internships including: 1) student work discipline is less than optimal, 2) student social relations and mechanics in the industry are not well established, 3) the work culture applied by students is still not optimal, 4) the sense of responsibility for the work given is lacking. This problem indicates that there are indications that the implementation of practical still has less than optimal results. 
Industrial Work Practical implementation has a good success rate in planning, implementation, and evaluation as stated in the practical guidelines. The success rate of practical implemented by SMK Negeri 1 Manduamas can be known by carrying out an evaluation. The evaluation was carried out to determine the level of conformity between the implementation of the program implemented by the school and the practical guidelines. Evaluation is a systematic process of describing, obtaining, reporting, and applying descriptive information and assessing that information about the merits of some objects, appropriateness, honesty, safety, meaning and fairness [2].

\section{THEORETICAL DESCRIPTION}

\subsection{Vocational High School}

Vocational Education is a form of formal education that organizes vocational education at the secondary education level as a continuation of SMP/MTs or other equivalent forms or continuation of learning outcomes that are recognized as equal/equivalent to SMP/MTs [3]. With a specialization in preparing graduates to be ready to work.

\subsection{Industrial Work Practice Management}

Author [5] argues that the management of industrial work practices interpreted as everything related to the management of industrial work practice processes to achieve the goals that have been set, both short-term goals, medium-term goals, and long-term goals. In addition [6] explain in his thesis explained that the management of industrial work practices is carried out starting from the planning, organizing, implementing, and evaluating stages.

\subsection{Industrial Work Practice}

Industrial Work Practices derived from the term Dual System Education are carried out in order to achieve the goal of relevance of education to the demands of manpower needs. Dual system education is an implementation of the link and match concept, namely curriculum design, learning processes, and the implementation of evaluations designed and implemented jointly by the school and industry [4].

\subsection{Purpose of Industrial Work Practice}

The purpose of Industrial Work Practice are a) to produce workers who have professional skills, namely workers who have a level of knowledge, skills and work ethic in accordance with the demands of the job market. b) Improve and strengthen the link and match between educational and vocational training institutions and the world of work, c) Improving the efficiency of providing professional quality education and training for workers, by utilizing existing training resources in the world of work, and d) Giving recognition and appreciation of work experience as part of the educational process [7]

\section{METHOD}

The type of research used in this study is a descriptive qualitative approach, which describes the state of the object to be studied as it is in accordance with the situation and conditions in the field. Data collection techniques through interviews and documentation. Data analysis was carried out starting from data reduction, data presentation and drawing conclusions. The location of this research is at SMK Negeri 1 Manduamas, which is located in South Tapanuli Regency. The subjects in this study amounted to 11 people consisting of elements from the principal, vice principal of the public relations department, head of the department, chairman of the industrial work practice committee, public relations secretary, and several students participating in the practice.

\section{RESULT AND DISCUSSION}

\subsection{Planning}

Planning for industrial work practices at SMK Negeri 1 Manduamas is carried out at the beginning of the new school year, in class XI. Some of the activities carried out at the planning stage of industrial work practices at SMK Negeri 1 Manduamas, namely needs analysis, industrial mapping, socialization, selection of practice sites and appointment of supervising teachers, as well as debriefing for students. The planning activities of industrial work practices at SMK Negeri 1 Manduamas are almost in line with the opinion of [8] in his research at SMK Sidikalang, Dairi Regency that the Industrial Work Practical preparation activities are determining industries, preparing administration or letters for industry and permission letters for parents of students who will hold practice, providing briefing to students before going to the field in the form of providing knowledge, skills, and how to learn in their respective places of practice.

\subsubsection{Needs analysis}

The main analysis of practical needs is the budgeting process that will be used for purposes related to industrial work practice activities. Budgeting is adjusted to the number of students who will practice as well as the accumulation of needs such as facilities, transportation costs, and other needs [9]. Specifically, for funds used in industrial practice activities, it comes from the government and students themselves. All budgets will be used for activities such as exploration costs to industry, supplies, deliveries, monitoring, withdrawals and costs for the procurement of other facilities and infrastructure [10]. The above statement is supported by [11] that the school prepares the needs of students who will carry out practices such as the provision of practical facilities, cost estimates with the existing school budget. 


\subsubsection{Industrial Mapping}

Industrial mapping is the initial activity in the internship program carried out by the public relations department. The purpose of industrial mapping is to find out which industries are right for the location of students carrying out practices that are in accordance with the competencies of students. This is in line with the opinion of [3] that the mapping of industrial practice sites is very important before the training program is designed. This is intended so that the world of work that is used as a partner is truly in accordance with the expertise program being occupied by students, so that the internship objectives are achieved properly.

\subsubsection{Socialization}

Socialization activities in the implementation of practical activities in this study are activities of delivering information to students, supervising teachers, and parents of students participating in the practice. How the rules for students and teachers and what are the obligations that parents must obey [8]. The socialization activity was carried out by gathering parents, students and teachers at the school and providing information about the procedures for implementing the practice for students.

\subsubsection{Determination of Practice Places and Supervising Teacher}

After students submit the desired place of practice, the practice committee will analyse and contact the industry. This is in line with the opinion of [4], that basically the principle of the stages of the management process is the placement of people who are in accordance with their competencies. Furthermore, the appointment of supervising teachers for practical students consisting of productive subject teachers.

\subsubsection{Debriefing}

The debriefing is carried out in schools with the aim of equipping participants with industrial science work practices and everything to be used while in practice. There are two stages of debriefing, firstly general debriefing related to industrial work practice material and special debriefing related to material from each department. The material in the debriefing activity is related to general and technical explanations of the implementation of industrial work practices, report generation, student obligations and mental strengthening in carrying out industrial work practices as well as what to bring to the practice.

\subsection{Actuating}

The implementation of industrial work practices are activities after the planning activities are completed, the period of implementation of industrial work practices that must be taken by students, which is approximately 6 months or 1 semester, consists of:

\subsubsection{Submission}

Submission activities are carried out according to the schedule and the results of the agreement with the industry, students will be escorted to the practice site based on the recapitulation of the place that has been prepared by the committee. The transfer of students to industry is carried out by teachers who are given assignments and when they arrive at the practice the teacher explains again about the competencies possessed by students and what types of work students can do.

\subsubsection{Monitoring}

The monitoring implementation at SMK Negeri 1 Manduamas is carried out after the industrial work practice period lasts for 1 month or 1 and a half months. The school will periodically monitor at least 2 times in industrial work practices. The industrial practice committee will arrange a schedule and the names of the teachers who are assigned the task of monitoring. Monitoring is also carried out to determine the suitability of student competencies with the work carried out in the practice.

The things that are monitored by the supervising teacher are the suitability of the field of work with student competencies by looking at journal books or asking students directly to see activities in the field whether they have problems or not, get any facilities, and whether their working hours are in accordance with the provisions. The purpose of this monitoring is in line with the opinion of [3] that the purpose of monitoring is to see the progress of student learning, both in terms of attitudes and skills.

\subsubsection{Assessment}

Assessment or evaluation is carried out after the practice period is over. Done before the withdrawal schedule arrives no later than 3 days. The assessment is fully the authority of the industry or the field. The assessment is carried out by referring to the aspects that have been listed in the journals of each department. The intended technical aspect is the level of mastery of the skills of the practical participants in completing the work. While the non-technical aspects are intended to be the attitudes and behaviours of practical participants while at work which involve: discipline, motivation, alertness, initiative, responsibility, personality, appearance, hospitality, cooperation, and so on.

\subsubsection{Withdrawal}

The withdrawal of practical students is carried out in accordance with the withdrawal assignment letter from the school. The above is in accordance with the opinion of [7] about several stages of industrial practice management, namely the withdrawal of practical students from their respective places. Based on the results of the analysis of the withdrawal of practical students at SMK Negeri 1 Manduamas, it was carried out by the 
supervising teacher in accordance with the assignment letter from the school.

\subsubsection{Reporting}

After completing the practice, students will return to school to collect activity reports during the practice which are approved by the industry or industry leaders, in the form of journals and assessment certificates obtained from the practice. At SMK Negeri 1 Manduamas, reporting activities are mandatory for students participating in the practice. This is in line with the opinion [12], that at the end of the internship program, students compile reports on activities carried out in the industry and take competency tests.

\subsection{Evaluating}

Evaluation of industrial work practices at SMK Negeri 1 Manduamas is done by collecting data from student reports first. The purpose of collecting data is to determine the level of achievement of industrial work practice targets. This is in accordance with the opinion of [5] that evaluation needs to be done to see the suitability between the program and its implementation. Evaluation is carried out by: 1) analysing the results of reports made by students and the results of assessments carried out by their respective supervisors from the world of work, 2) exposure to the results of each student's practice, 3) competency testing, namely students are assigned to do work techniques according to their area of expertise.

Based on the results of research on practical evaluation at SMK Negeri 1 Manduamas, evaluation activities are carried out after the withdrawal of students from the practice site is complete. Evaluation is carried out in order to get better input for further industrial work practice activities. Unfortunately, the school did not involve the industry in the evaluation activity, even though the industry could provide input and advice considering its role as a supervisor who observes student progress during practice.

\section{CONCLUSION}

Planning for industrial work practices at SMK Negeri 1 Manduamas is carried out at the beginning of the new school year, in class XI ( $3^{\text {rd }}$ or $4^{\text {th }}$ semester $)$.

The implementation of industrial work practices at SMK Negeri 1 Manduamas is carried out according to the schedule and the result of an agreement with the place of practice, which is approximately 6 months or 1 semester.

Evaluation of industrial work practices at SMK Negeri 1 Manduamas is done by collecting data and analyzing it. Each department will report the results of student internships.

\section{REFERENCES}

[1] Regulation of the Minister of Industry Number 03/M IND/PER/1/2017. Coaching Guidelines and Middle School Development Competency-Based Vocational.

[2] Juliani, W. iffah, \& Widodo, H. (2019). Integrasi Empat Pilar Pendidikan (Unesco) Melalui Pendidikan Holistik Berbasis Karakter Di SMP Muhammadiyah 1 Prambanan. Jurnal Pendidikan Islam, $\quad 10(2)$ 65-74. https://doi.org/10.22236/jpi.v10i2.3678

[3] Sihotang, D. O., Siburian, P., Darwin, \& Siburian, P. (2020). Implementation of Character-Based Industrial Work Practices in SMK Arina Sidikalang. 384(Aisteel),

459-463. https://doi.org/10.2991/aisteel-19.2019.101

[4] Umiati, Umiati (2016) PENGELOLAAN PRAKTEK KERJA INDUSTRI (PRAKERIN) DI SMK NEGERI 2 DEPOK SLEMAN YOGYAKARTA. Thesis, Universitas Negeri Yogyakarta.

[5] Sihotang, Din Oloan (2017) PENGEMBANGAN MODEL PROGRAM PRAKTEK KERJA INDUSTRI SISWA BERBASIS KARAKTER BATAK DI SMK KECAMATAN SIDIKALANG. Masters thesis, UNIMED. http://digilib.unimed.ac.id/27261/

[6] Sunyoto, S., Khumaedi, M., \& Suharmanto, A (2015). Model Pelaksanaan Praktik Kerja Industri Pada Sekolah Menengah Kejuruan (Smk) Yang Berorientasi Pada Penyiapan Siswa Untuk Menjadi Technopreneur. Jurnal Penelitian Pendidikan Unnes, $\quad 32(1), \quad 125728$. https://doi.org/10.15294/jpp.v32i1.5706

[7] Selvarajoo, S., Raja Ghazilla, R.A. and Mamat, A. (2021), "Industrial practices of collaborative manufacturing involving tool and die development: Malaysian perspective", Journal of Manufacturing Technology Management, Vol. 32 No. 2, pp. $485-$ 505. https://doi.org/10.1108/JMTM-07-2019-0266

[8] Sihotang, D., Dewi, R., \& Matondang, Z. (2017). Development of a Batak Character-Based Of Industrial Work Practices Management Model in Vocational High School Sidikalang. https://www.iosrjournals.org/iosr-jrme/papers/Vol7\%20Issue-4/Version-5/D0704052330.pdf

[9] Khusaini, Mutiah, \& Ramdani, H. C. (2021). Vocational and senior high school differences in financial literacy. IOP Conference Series: Earth and Environmental Science, 747(1). https://doi.org/10.1088/1755-1315/747/1/012018 
[10] Setiaji, Khasan. (2015). The Importance of Financial Education for Vocational School Students in Indonesia (A Case Study in Business and Management Program of Vocational High School (SMK) in Semarang City).

[11] DO Sihotang. (2020) Principal of Education Financing. Bunga Rampai EKONOMI DAN PEMBIAYAAN PENDIDIKAN. Zifatama Jawara: Sidoarjo

[12] Putra, Z. A. (2016). Early phase process evaluation: Industrial practices. Indonesian Journal of Science and Technology, 1(2), 238-248. https://doi.org/10.17509/ijost.v1i2.3808 